\title{
Capacity Building in Cyber Security to Make India Secure to go Cashless
}

\section{Chitra, Sumangala Devi}

\begin{abstract}
Recent developments have accelerated to move in India towards a Cashless economy. The Jan Dhan Yojana (Jan Dhan Government Scheme) announced in 2014 is providing for the cost free creation of a bank account for every Indian family. Each bank account is also accompanied by a Rupay Debit card for withdrawing money deposited in the account. The currency demonetization at the end of the year 2016, with the removal of certain denomination of bank notes. The additional initiatives and service offerings are also now encouraging the use of cashless transaction via, online banking, payment cards, e-wallets, direct carrier billing and crypto currency. A study said, as India changes to a large scale economy, cyber dangers are in a new high with the amount of these incidents happening in banking methods rising in the previous five decades. The research demonstrated that demonetization has provided an impetus into e-wallet providers and cellular wallets have seen a huge growth in downloads. Additionally, cyber- risks will only grow as India will be seeing a change towards a strong economy. The kinds of cyber security events like Phishing, scanning, site intrusions and defacements, virus code and denial of service attacksmay keep growing. The joint research by Assocham and PWC stated on ATM card hackstruck on the Indian banks in October this past year, impacting approximately 3.2 million debits. The cyber strikes on Indian sites have increased almost five times before four decades.
\end{abstract} Scanning. Website intrusions.

\section{INTRODUCTION} effect on several sectors of the Indian market and has substantially influenced the way people transact in daily life. From midnight of 8 November2016, 500 INR along with 1000 INR notes ceased to be regarded as legal tender. Though the government's goal was to stop the counterfeiting of money, black cash, tax evasion and terrorism financing demonetization also had a direct influence that the way people banking in India. When the Indian Government recently banned two high-values currency notes, it led to all kinds of and ATM's. And that in a state where over half of its taxpayers don't own a bank account. But as the dust continues to pay, a concrete long-term advantage of this method seems to be emerging: shifting India to a digital market where digital transactions play an important part in the monetary system. The rush to get this done, however, is most very likely to create a spike in cybercrime.

Revised Version Manuscript Received on 16 September, 2019.

Dr. I. Chitra, Assistant Professor of Economics, PG \& Research Department of Economics, Thiagarajar college, Madurai, India

Dr. Sumangala Devi, Associate Professor of Commerce, M.O.P. Vaishanav college for women, Chennai, India.
Index Terms: Cashless Economy, Cyber-threats, Phishing,

The current demonetization movement has had an enormous choes. It led to enormous queues to exchange cash at banks

The demonetization initiative of this administration of India is very likely to raise the rate of deployment and development of electronic services, thus allowing the transition from a cashless economy. With electronic India, the basis for transforming India into an empowered and knowledge market was laid. Cyber security the security of valuable intellectual property, company information and monetary transactions in electronic type against theft and abuse is an increasingly crucial issue. Given the increasing rate and sophistication of risks and also to transparent focus on recognizing a more cashless market. The government was investing in a variety of reforms for higher financial inclusion. So after the demonetization proceeds, the market was prepared with the entire infrastructure needed tohave a jump towards a democratic society. On its own part, RBI and National payments firm of India (NPCI) leveraged technologies introduced newer route for banking together with the general aim of enhancing customer experience protection and simplicity of trades.

\section{THE EVOLUTION OF INDIA'S FINANCIAL INFRASTRUCTURE}

The Evaluation of India's financial infrastructure can be divided in to three phases.

\begin{tabular}{|c|c|c|}
\hline $\begin{array}{l}\text { Ist phase of Technology } \\
\text { Initiatives }\end{array}$ & $\begin{array}{l}\text { IInd Phase of Technology } \\
\text { Initiatives }\end{array}$ & $\begin{array}{l}\text { IIIrd Phase of Technology } \\
\text { Initiative }\end{array}$ \\
\hline $\begin{array}{l}\text { 1984: Introduction of } \\
\text { Magnetic Ink Character } \\
\text { Recognition (MCR) } \\
\text { 1987 First ATM technology } \\
\text { installed in Kolkata. }\end{array}$ & $\begin{array}{l}2001 \text { Internet Banking } \\
\text { 2004-2005 Real time Gross } \\
\text { Settlement (RTGS) } \\
\text { National Electronic Fund } \\
\text { Transfer (NEFT) } \\
2007 \text { : Mobile Banking } \\
2008 \text { Cheque transaction } \\
\text { systems }\end{array}$ & $\begin{array}{l}\text { 2010: Immediate Payment } \\
\text { Service (IMPS) } \\
\text { 2012: Adoptionof ISO-20022 } \\
\text { Messaging standard in the } \\
\text { Next Generation RTGS (NG- } \\
\text { RTGS) System } \\
\text { 2014 Jan Dhan Yojana } \\
\text { National Unified USSD } \\
\text { platform, Ru-paycard Bharat } \\
\text { Bill Payment system (BBPS) } \\
\text { 2016 Unified payment } \\
\text { Interface (UPI Payment } \\
\text { banks, mobile wallets } \\
\text { 2017 Bharat Interface for } \\
\text { Money (BHIM) app } \\
\end{array}$ \\
\hline
\end{tabular}

Sources:www.pwc.in, ASSOCHAM securing the Cashless Economy

\section{CYBER SECURITY IN CASHLESS ECONOMY}

With more programs being contained from the banking ecosystem, the resources of trade origination will observe a substantial growth which signifies cyber dangers will continue togrow. Additionally, cyber dangers willonly grow as India will be seeing a change towards a cashless market with much more timeto discover and time to react to these strikes the yield on investments such as cyber-attacks is far higher in emerging markets such as India compared to developed economy like US.

Since the nation is undergoing an electronic revolution, theeffect of the transformation makes it critical for financial

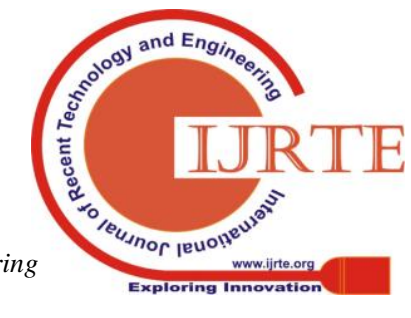


support playersto reevaluate their cyber safety resilience. The amount of incidents happening in banking methods has improved inthe previous five decades. At the month ofOctober 2016, on ATM card hack struck Indian banks, impacting around 3.2 countless debitcards. Hence attempts are required toimprove cyber security since citizens and business adopt this new electronic tide.

\section{OBJECTIVES}

1) To study the various Digital payments in India facilitating a Cashless economy.

2) To create awareness on capacity building in cyber security enabling India to move towards a secured Cashless economy.

\section{REVIEW OF LITERATURE}

The 21st Century has seen enormous technological progress in just about all spheres of human effort. The most conspicuous is that the system of communication and information technologies that has mystified pc and took the globe on a quick strip turning it into a global village in which people of various nationalities races and societal history can efficiently interact. (Adela, 2001)

Based on 2015 report Cost water House Coopers, India's unbanked population has been at 233 million. Even for Individuals using banks, the capability to use their credit or debit card is restricted since there are just about 1.46 million purpose of sale that takes payments through cards. An analysis by Boston consulting team and Google at July noted that pocket users have already surpassed the Amount of Mobile banking customers and are 3 times the amount of credit card consumers.

\section{RESEARCH METHODOLOGY}

In pursuance of above aims the next research methodology has been utilized for this research. The goals of the research were achieved through analysis and collection of secondary information. These condary information has been largely drawn from several documents and books of Reserve Bank of India (RBI), Digital India, National Payments Corporation of India (NCPI) and also Journals and Websites. The information sets were mathematically utilizing the easy percent, whilst significance and analysis of variance (ANOVA) testshave been used in analyzing Hypothesis I and II respectively

\section{ANALYSIS OF DATA}

A cashless or an Electronic Market will need all the occupants to have a bank account.

This will lead to higher fiscal inclusion prices and also can help capacity building and recognition of cashless market impart education associated with the electronic payment ecosystem and promote citizens particularly in rural and semi-urban regions to utilize digital payments in addition to some other goods and services provided by Digital India.

\section{DIGITAL PAYMENTS ECOSYSTEM}

1. Digital Payments- definition

The Payment and settlement Act 2007 has defined Digital Payments. "As per this any electronic funds transfer means any transfer of funds which is initiated by a person by way of instruction, authorizations or order to a bank to debit or credit an account maintained with that bank through electronic means and includes point of sale transfers: Automated Teller Machine transactions, direct deposits or withdrawal of funds transfer initiated by telephone internet and card payment"

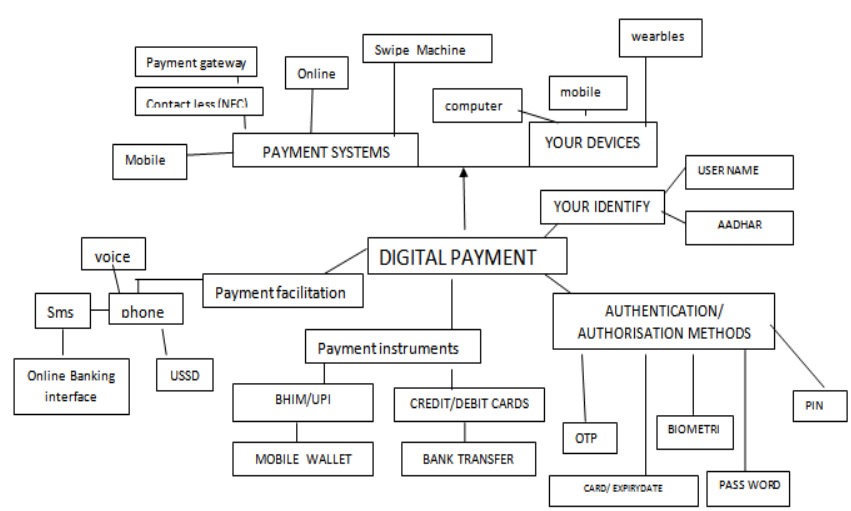

SOURCES: MEITY

Lately Government has accepted a range of measures to ease and interrogate the movementto an electronic market including (a) Launch of this BHIM (Bharat Interface forMoney) program for smart phones that's predicated on the newest Unified Payment Interface (UPI). This has generated Inter-operability of electronic transactions. The 250 million electronic have to utilize their smart mobile to create easy and rapid payments.(b) Launch of BHIM USSD 2.0, an item which allows the 350 Million attribute telephone users to make the most this UPI. (c) Launch of Aadhaar Merchant cover targeted at the 350 million that don't have mobiles.(d) Reduction in prices (Merchant discount fee) paid DigitalTransaction and Transaction Using the UPI. Present 1.5 million, through cost discounts. There also have been relaxations of limitations on the usage of paymentwallets. Tax advantages also have been supplied to incentives digital trade.

Table 1.1

KEY BARRIERS TO DIGITAL PAYMENTS

\begin{tabular}{|c|l|c|}
\hline S.No & \multicolumn{1}{|c|}{ K.B to D.P } & $\begin{array}{l}\text { Percentage } \\
(\%)\end{array}$ \\
\hline 1 & Habit to use cash & 68 \\
\hline 2 & Complexity of using & 55 \\
\hline 3 & Lack of compelling & 48 \\
\hline 4 & Intertia of Non-cash Method & 33 \\
\hline 5 & $\begin{array}{l}\text { Incentives/ offers from other } \\
\text { methods }\end{array}$ & 29 \\
\hline 6 & Fraud/hidden charges & 27 \\
\hline 7 & Reach & 16 \\
\hline
\end{tabular}

Sources: Express Computer Online.com 
Table 1.2

Budget Allocation towards cyber Security- threats in India

\begin{tabular}{|c|c|c|}
\hline $\begin{array}{c}\text { S1. } \\
\text { No }\end{array}$ & Year & $\begin{array}{l}\text { Cyber Security } \\
\text { Threats } \\
\text { Budget Allocation in } \\
\text { Crs. }\end{array}$ \\
\hline 1 & $2012-2013$ & 36.06 \\
\hline 2 & $2013-2014$ & 42.37 \\
\hline 3 & $2014-2015$ & 62 \\
\hline 4 & $2015-2016$ & 85 \\
\hline 5 & $2016-2017$ & 110 \\
\hline 6 & $2017-2018$ & 150 \\
\hline 7 & $2018-2019$ & 775 \\
\hline
\end{tabular}

Sources: Express Computer Online.com

Table 1.2 shows that "government has initiated action to create a national level mechanism to counter cyber security threats with a financial outlay Rs.775/- Crores to be spent in the year 2018. The budget allocation for Cyber security programme has steadily increases from Rs. 36.06 Crores during 2012-2013 to Rs. 85 Crores during2015-2016. The budget allocations during the year has increased 2012-2013, 2013-2014, 2014-2015 and 2015-2016 were Rs. 36.06 Crores, Rs.42.37 Crores, Rs.62 Crores and Rs.85 Crores respectively.

As India shifts to a cashless economy, Cyber-threats are at a new high with the number of such incidents occurring in banking system increasing in the last seven years. A study said on by Assocham and PWC said that an ATM card hack hit the Indian banks in affecting around 3.2 billion debit cards. During the growing threats, India's budgetary allocation towards cyber security was about Rs.775 Crores in 2018-2019 from 36.06 Crores in 2012-2013. The study revealed that demonetization has given an impetus to e-wallet services and mobile wallets have witnessed massive rise in app downloads. Moreover, cyber threats will only rise as India is seeing a shift towards a cashless economy. The types of cyber security incidents such as phishing, Scanning, website intrusion and defacements virus code and denial of service attacks will continue to grow".

\section{THE FUTURE IS DIGITAL}

Digital payments have accelerated the move in India towards a cashless economy. Than Jan Dhan Yojana announced in 2014, providing for the cost -free creation of a bank account for every Indian family. Each bank account is also accompanied by a Rupay debit card for withdrawing money deposited in the account. The currency demonetization at the end of year 2016 with the removal of certain denominations of banknotes from circulation is another example. Additional initiatives and service offering are also now encouraging the use of cashless transactions via online banking payment cards, e-wallets, direct carrier billing and crypto-currency.
Table 1.3

DIGITAL PAYMENT MARKET IN INDIA

\begin{tabular}{|c|c|c|c|c|}
\hline SL NO & $\begin{array}{c}\text { Digital } \\
\text { transaction }\end{array}$ & $\begin{array}{c}\text { User Base } \\
\text { (millions) }\end{array}$ & $\begin{array}{c}\text { Number of } \\
\text { Offline } \\
\text { Merchants } \\
\text { (Millions) }\end{array}$ & $\begin{array}{c}\text { Transactions } \\
\text { (Millions) }\end{array}$ \\
\hline 1 & Pay-tm & $350(58.33 \%)$ & $950(62.78 \%)$ & $150(10.56 \%)$ \\
\hline 2 & G-Pay & $25(4.17 \%)$ & $120(7.95 \%)$ & $860(60.56 \%$ \\
\hline 3 & MOBIWIK & $107(17.83 \%)$ & $143(9.45 \%)$ & $300(21.12 \%)$ \\
\hline 4 & PHONEPE & $118(19.67 \%)$ & $300(19.82 \%)$ & $110(7.76 \%)$ \\
\hline & Total & 600 & 1513 & 1420 \\
\hline
\end{tabular}

Sources: http://www.livemint.com

Table 1.3 shows that the transaction of digital modes of payment in UPI, WALLET payments bank has increased through has increased through $58.33 \%$ percent in pay-tm. Number of offline merchants has also rise 62percent in paytm.The gross transactions at 0.4 percent for small merchants. Most fintech firms are offering payment service for free. We believe this downward trend will continue, where payment will be offered for free and players will look for monetize the data through sale of other financial and non-financial products.

\section{ANOVA}

"The name Analysis of variance was derived based on the approach in which the method uses the variance to determine the means whether they are different or equal. Null hypothesis states that the all population means are equal. The alternative hypothesis is proves that at least one population means is different.

\section{$\mathrm{H}_{0}: \mu_{1}=\mu_{2}-\mu_{3}$ (Null hypothesis)}

$\mathrm{H}_{1}: \mu_{1} \neq \mu_{2} \neq \mu_{3} \quad$ (Alternative hypothesis)

\section{Test of Hypothesis}

The digital transaction of cashless economy has insignificant impact of cyber security. This hypothesis was tested with the analysis of variance using the information Table 1.3 at 0.05 Level of insignificance”.

\section{ANOVA TABLE}

\begin{tabular}{|l|l|l|l|l|l|l|}
\hline $\begin{array}{l}\text { Sources } \\
\text { of } \\
\text { variance }\end{array}$ & $\begin{array}{l}\text { Sum of } \\
\text { square }\end{array}$ & $\begin{array}{l}\text { Degrees } \\
\text { of } \\
\text { freedom }\end{array}$ & $\begin{array}{l}\text { Mean of } \\
\text { square }\end{array}$ & F ratio & P.Value & F. critical \\
\hline $\begin{array}{l}\text { Between } \\
\text { group }\end{array}$ & 182024.2 & 2 & 91012.1 & 1.662706 & 0.266348 & 5.143253 \\
\hline $\begin{array}{l}\text { Within } \\
\text { group }\end{array}$ & 328424 & 6 & 54737.33 & - & - & - \\
\hline Total & 510448.2 & 8 & - & - & - & - \\
\hline
\end{tabular}

Sources: Critical value at 0.05 level of insignificance with 2 to 6,8 degree of freedom

\section{Decision Rules}

Since the calculated value of F. ratio 1.66 less than the F critical value of 5.14. the alternative hypothesis is rejected and null hypothesis is accepted. There is no relationship between pay-tm, g-pay and mobiwik and phonepe. $\mathrm{P}$ value is above 0.05 , therefore we can accept the null hypothesis and reject the alternative hypothesis. We can therefore, conclude that a different significant of digital payment

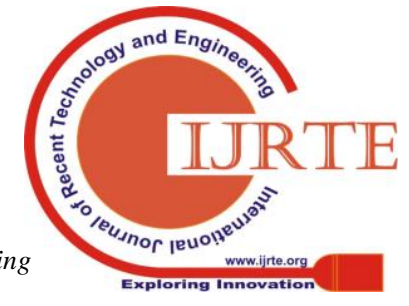


markets in India towards a cashless economy and cyber security. People were can use different mode of digital transaction through the ICT in India. Based on the Anova result above, it is clear that the cyber security go cashless, which was different significant level in the usage of Pay-tm, wallets, G-pay, mobiwik and phone-pe.

Correlation

"The statistical relationship between two variables is referred to as their correlation. A correlation could be positive, meaning both variables move in the same direction or negative, meaning that when one variables value increases the other variables values decrease.

Here $r=+1.0$ describes a perfect positive correlation

$r=-1.0$ describes a perfect negative correlation.

Formula $\mathrm{r}_{\mathrm{xy}}=\sum\left(\mathrm{x}_{\mathrm{i}}-\dot{\mathrm{X}}\right)\left(\mathrm{y}_{\mathrm{i}}-\mathrm{y}\right)$

$$
\sqrt{\sum\left(\mathrm{x}_{\mathrm{i}}-\mathrm{x}\right)^{2} \sum\left(\mathrm{Y}_{\mathrm{i}}-\mathrm{y}\right)^{2}}
$$

rxy $\Rightarrow$ the correlation coefficient of the linear relationship between the variables $x$ and $y$

$\mathrm{X}_{\mathrm{i}} \Rightarrow$ the value of the $\mathrm{x}$ - variable in a sample

$\mathrm{X} \Rightarrow$ the mean of the values of the variable

$\mathrm{y}_{\mathrm{i}} \Rightarrow$ the value of the $\mathrm{y}$ variables in a Sample

$y \Rightarrow$ the means of the values of $y$ variables.

Table 2.1 shows a decrease in the total paper clearing in electronic payments which means clearing of paper based transactions / paper mode financial settlements (usually cheque has been decreased). The decreased operation in paper clearing denote that all the monetary transactions are transforming from paper to paper less which means electronic mode of operations were demanded than paper tools of, payment and receipts. A correlation could be described a perfectly negative. The correlation co-efficient value (-0.90459) in 2012-13 the paper clearing almost more than one -lakh billion $(1,00,182)$ were reduced to 81,892 billion rupees in 2017-2018” .

Table 2.1

Total paper clearance

\begin{tabular}{|c|c|}
\hline Year & $\begin{array}{c}\text { Amount } \\
\text { (in billions of } \\
\text { rupees) }\end{array}$ \\
\hline $2012-2013$ & $1,00,182$ \\
\hline $2013-2014$ & 93,316 \\
\hline $2014-2015$ & 85,439 \\
\hline $2015-2016$ & 81,861 \\
\hline $2016-2017$ & 80,958 \\
\hline $2017-2018$ & 81,893 \\
\hline
\end{tabular}

Sources: compiled from various report of RBI

Result

Correlation of total paper clearance

\begin{tabular}{|l|l|l|}
\hline & $\mathrm{X}$ & $\mathrm{Y}$ \\
\hline $\mathrm{X}$ & 1 & - \\
\hline $\mathrm{Y}$ & $-0.90459^{*}$ & 1 \\
\hline
\end{tabular}

Correlation coefficient $(-0.90 *)$ negative correlation decreasing $\mathrm{Y}$ value increasing $\mathrm{x}$ values

\section{National Electronic Fund Transfer (NEFT)}

Table 2.2 represents the individual status of one of the electronic payment method National Electronic Fund Transfer continuously has been increased during 2012-2013 (29,022 .40 billions) to 2017-2018 (1,72,229 billions). A consecutive improvement had achieved through this mode of operation. A correlation could be described a perfectly positive. The correlation value $(+0.967576)$

Table 2.2

National Electronic Fund Transfer (NEFT)

\begin{tabular}{|l|l|}
\hline Year & $\begin{array}{l}\text { Amount } \\
\text { billions of rupees) }\end{array}$ \\
\hline $2012-13$ & $29,022.40$ \\
\hline $2013-14$ & $43,785.50$ \\
\hline $2014-15$ & $59,803.80$ \\
\hline $2015-16$ & $83,273.00$ \\
\hline $2016-17$ & $1,20,040.00$ \\
\hline $2017-2018$ & $1,72,229.00$ \\
\hline & \\
\hline
\end{tabular}

Sources: complied from the various reports of RBI

\section{Correlation NEFT}

\begin{tabular}{|l|l|l|}
\hline & $\mathrm{X}$ & $\mathrm{Y}$ \\
\hline $\mathrm{X}$ & 1 & - \\
\hline $\mathrm{Y}$ & 0.967576 & 1 \\
\hline
\end{tabular}

\begin{tabular}{|l|l|l|}
\hline & $\mathrm{X}$ & $\mathrm{Y}$ \\
\hline $\mathrm{X}$ & 1 & - \\
\hline $\mathrm{Y}$ & 0.967576 & 1 \\
\hline
\end{tabular}

Correlation co-efficient (0.96) positive correlation increasing $\mathrm{x}$ values and increasing $\mathrm{y}$ values.

\begin{tabular}{|c|c|c|c|}
\hline $\begin{array}{l}\text { Serial } \\
\text { number }\end{array}$ & $\begin{array}{l}\text { Variable } \\
\text { name }\end{array}$ & $\begin{array}{l}\text { (a) in } \\
\text { correlation }\end{array}$ & @@ in correlation \\
\hline 1 & NEFT & 6 & $0.968 * *(0.02)$ \\
\hline 2 & $\begin{array}{l}\text { Total paper } \\
\text { clearance }\end{array}$ & 6 & $-0.905(0.013)$ \\
\hline
\end{tabular}

To examine the correlation between complete newspaper clearance, NEFT and amount of years that the time period required for evaluation will be 2012-2013 to 2017-2018 intervals..The Karl Pearson's correlation coefficient is calculated for all these intervals for India accept evaluation based upon the access to information.

The correlation coefficients are analyzed against the null hypothesis that their worth is equivalent to zero with the entire $\mathrm{t}$ test. A positive and significant correlation suggests a high level of association between amount of paper and years clearance along with NEFT. The significance exercised for India through the interval is in Table.

The substantial correlation signaled that NEFT was an instrumental element in NEFT trade in India. The correlation coefficients between amount of decades and newspaper

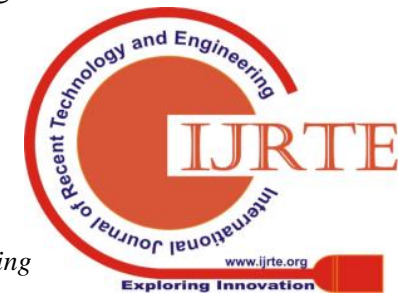


clearance isn't important in India, they don't imply a statistically significant association between amount of decades and newspaper clearance in these types of scenarios.

\section{CONCLUSION}

The digital India programme is a flagship programme of the government of India having a vision to convert India into a digitally empowered society and knowledge economy. Faceless, paperless India is just one of professed part of electronic India. India is among the biggest markets such as smart phones and cellular programs, providing an effortless transition involving a less money market. The neighborhood markets have accepted the transition into paperless transactions. Banking and payment gateways are shortly changing towards payment via smart telephones. Therefore it may be seen from the study that both in the national and individual level, there's a conscious attempt to move in the cash-based culture towards a cashless economy. The analysis stated that by identifying cyber safety flows and dilemmas that the decision-makers are going to be better positioned to implement proper security controls layout extra secure architecture track targeted assaulted and keep powerful cyber durability because of their IT, OT and ICT web functions. Thus, efforts are essential to boost cyber Security Company and taxpayers adopt these new electronic waves.

\section{REFERENCE}

1. https://m.economictimes.com

2. https://parenting.firstcry.com

3. https://www.livemint.com

4. economictimes.indiatimes.com/industry/banking/finance/banking

5. Khan, M., \& Ayyoob, M. O. H. A. M. M. A. D. (2017). Computer security in the human life. International Journal of Computer Science and Engineering (IJCSE), 6(1), 35-42.

6. www.pwc.inAssocham securing the cashless economy.

7. Press-CERT-Fin Report

8. Kumari, R. L. (2018). India's Digital Transformation: Driving MSME Growth.

9. Academic rigour.journalisticflaix.

10. BK, P., HL, M., \& Kumar, A. (2016). A Comprehensive Study of Various Kinds of Frauds \& It's Impact. International Journal of Computer Science Engineering and Information Technology Research (IJCSEITR) ISSN (P), 2249-6831.

11. KG, M. (2017). Post Demonetisation Scenario in India. IMPACT: International Journal of Research in Humanities, Arts and Literature, $5(11)$. 